\title{
The Voice of the Unheard: Ian McEwan's Nutshell as Cultural Criticism
}

\author{
Duyulmayanın Sesi: Kültür Eleştirisi olarak Ian McEwan'ın \\ Fındık Kabuğu Romanı
}

\section{Funda CIVELEKOĞLU*}

\begin{abstract}
Ian McEwan's 2016 novel, Nutshell portrays an unusual narration in the voice of a foetus. The novel can be regarded as a postmodern reception of Shakespeare's Hamlet as is claimed by both reviewers and McEwan himself. Yet, McEwan has accomplished more than reviving Gertrude and Claudius of Hamlet, operating on Shakespearean poetics, and working with many other extratextual materials. While presenting intertextual playfulness, the novel also demonstrates the characteristics of psychological thriller and murder fiction and various treatises on art and literature. These meditations are quite noteworthy in that McEwan pushes the very limits of literary devices; that is to say, he integrates fiction and nonfiction into his novel. The story is told from the point of view of an unborn baby and is based on his impressions of what he hears and feels. The narrator is at a point between reliability and unreliability in that he sometimes vocalizes childish anxieties while observing the bitter aspects of the life he is part of and makes grave interpretations. Hence, Ian McEwan clarifies the fact that seeing cannot be the only source of true knowledge. Then, one can conclude that he is making a criticism of the enlightenment by allowing the reader to empathize with the experiences of a foetus and accentuating the significance of senses other than the eye. This article intends to show how Ian McEwan utilises postmodern literary devices to examine dualities, such as truth - falsehood, reality - illusion, art - life, innocence - guilt, good - evil, Eros - Thanatos, as instruments to question the so-called persistence of classicism.
\end{abstract}

Keywords: Ian McEwan, Nutshell, Enlightenment, Postmodernism, Narrator

Öz: Ian McEwan'ın 2016'da çıkan romanı Fındık Kabuğu, bir fetüsün dilinden sıradışı bir anlatım sergilemektedir. Romanın Shakespeare'in Hamlet'inin postmodern bir alımlanması olduğu yalnızca eleştirmenler tarafindan değil, McEwan tarafından da kabul edilmektedir. Ancak, Ian McEwan, Gertude ve Claudius'u diriltmek, Shakespeare şiirinin dizgelerini manipule etmek ve diğer birçok metin dişı malzemeyi kullanmaktan çok daha fazlasını başarmıştır. Roman, bir yandan metinlerarası oyunlara yer verirken, bir yandan da psikolojik gerilim ve polisiye kurgu özelliklerini yansıtır ve sanat ile edebiyat üzerine çeşitli bilimsel incelemeler ortaya koyar. Bu incelemeleri dikkate değer kılan McEwan'ın amacına edebi araçların sınırlarını zorlayarak ulaşmasıdır; bir başka deyişle, yazar kurmaca ve kurgusal olmayan düzyazı türlerini bir araya getirmektedir. Hikaye doğmamış bir bebeğin bakış açısından anlatılır ve onun duydukları ve hissettikleri ile ilgili izlenimlerine dayanır. Anlatıcının bazen, parçası olduğu hayatın acı yönlerini gözlemleyip çocukça kuşkularını dillendirirken yaşını aşan yorumlamalarda bulunması, karakterin güven ve güvensizlik uyandırması bakımından metinsel bir ikilemi de beraberinde getirmektedir. Ian McEwan, böylelikle, çıplak gözün tek başına doğru bilginin kaynağı olamayacağı gerçeğini de açıkça ortaya koymaktadır. Bu anlamda, McEwan'ın, okuyucunun tüm romanı bir fetüsün deneyimleri üzerinden anlamasına olanak tanıyarak ve vurguyu gözden ziyade diğer duyuların önemine atıfta bulunarak aydınlanma eleştirisi yaptığı sonucuna varılabilir. Bu makale, Ian McEwan'ın doğruluk - sahtelik, gerçeklik - yanılsama, sanat - hayat, masumiyet - suç, iyi - kötü, Eros Tanatos gibi ikilikleri irdelemek için postmodern edebi araçları klasisizmin sözde sürekliliğini sorgulamakta nasıl kullandığını göstermeyi amaçlamaktadır.

Anahtar sözcükler: Ian McEwan, Fındık Kabuğu, Aydınlanma, Postmodernizm, Anlatıcı

\footnotetext{
* Asst. Prof., Ege University, Deapartment of English Language and Literature, Izmir. fundacivelekoglu @ yahoo.com https://orcid.org/0000-0002-9986-9843

Bu arasında 11. IDEA Konferansı'nda (2017) sunulan bildirinin genişletilmiş ve değiştirilmiş versiyonudur.
} 
In his recent novel Nutshell, published in September 2016, Ian McEwan exhibits an extraordinary narration from the mouth of a foetus, placing his storyline between the words, "So here I am, upside down in a woman (1)," and "The rest is chaos (199)". The novel is said to manifest itself as a postmodern reception of Shakespeare's Hamlet as put not only by reviewers like Mark Medley, but also McEwan himself. Besides, the most frequently mentioned feature of the novel is that it tells the story of a foetus Hamlet, which is articulated right in the beginning by the epigraph taken from Hamlet, also accommodating the word "nutshell:" "Oh God, I could be bounded in a nutshell and count myself a king of infinite space - were it not that I have bad dreams". In this sense, McEwan has already heralded the "chaos" that we are to come across in an ironic manner in the "rest" of the novel.

Nutshell is so dense a piece of literature that makes it possible for readings from several points of view. Not only has Ian McEwan delivered his magnum opus in his literary career to date with Nutshell, he has also revived his early works in a way, which might supposedly be an indication of return to his habit of employing extraordinary narrators. Ian McEwan expressed this in his interview with Mark Medley, published in The Globe and Mail,

\begin{abstract}
In my early stories, written in the first half of the seventies, I had very improbable narrators who stood outside the world, looking in," says McEwan, 68. "I had, for example, a story narrated by an ape who's having a love affair with a woman - a novelist who's struggling with her second novel. And it was those kinds of dissociated narrators that I felt I was returning to (September 9, 2016).
\end{abstract}

At this point, as a personal observation, Nutshell also marks a revival of McEwan's idiosyncrasy in combining extraordinary images and instances with a postmodern Outlook in a classical manner. That is to say, one of the issues that renders him unique as a novelist is that he is able to come up with a perfect amalgamation of the classical and the avant-garde.

Apart from resurrecting Gertrude and Claudius, manipulating Shakespearean poetics, and dealing with many other extra-textual materials, Nutshell promises more than mere intertextual playfulness. The novel not only presents the features of a psychological thriller and detective fiction, but also demonstrates various treatises on art and literature. In this respect, the novel embodies together aspects of fiction and nonfiction. What renders these meditations remarkable is that McEwan fulfils his intention through using them as instruments of pushing the very limits of literary devices. The story is told from the point of view of an unborn baby and is based on his impressions of what he hears and feels. Employing an unborn baby as a narrator is technically an attempt to question the reliability of the narrator in that he is unable to see, and thus lacks "the most significant" sensory organ, sight. However, he is portrayed as an omniscient character, with all its possible connotations, contrary to what might be expected from him. The dysfunctionality of the enlightenment organ as far as the narrator is concerned, can be claimed as a reference to the Enlightenment all by itself. Yet, this point of absence also stands for a foreshadowing of how the omniaudient narrator in Nutshell becomes a challenge for breaking the boundaries of western enlightenment thought, "seeing is believing" along with the novel's manipulative attitude and playfulness. This article endeavours to acknowledge that McEwan's novel on the whole puts forward criticism of enlightenment ideals through challenging the textual, linguistic, stylistic, and artistic possibilities of a literary text. Although Nutshell has attracted the attention of readers, critics and reviewers mostly due to the extraordinary choice of the narrator and combining it with a Shakespearean twist, this choice also provides the possible grounds for multi-dimensional interpretations. Ian McEwan makes use of postmodern literary devices in order to scrutinize concepts such as truth - falsehood, reality - illusion, art - life, 
innocence - guilt, freedom - confinement, good - evil, Eros - Thanatos, as means to question the so-called persistence of classicism. Under these circumstances, the intention of this article is to analyse Nutshell as a cultural criticism, as far as concern the flaws of enlightenment and classicism.

The novel features a murder story set in contemporary London. The murder is planned against the foetus's father, John Cairncross by his mother, Trudy and her lover Claude, who is also her brother-in-law. The unborn baby "witnesses" every step of this evil plan and naturally empathizes with his poet and publisher father in relation with what he follows from the outside and what he feels in his mother's womb.

In the first place, the postmodern strategy of McEwan reveals itself in the context of space. The word "nutshell" explicitly indicates space as it signifies the shell of a nut which implies a sense of mystery in that the nut is not seen within the shell. In the case of this novel, it not only corresponds to the womb - foetus relation, but also becomes the expression of problematizing a two hundred-page novel, not actually brought about "in a nutshell." The protagonist, also the narrator of the novel has much to say, until he reaches the conclusion, which can be considered as both an end and a beginning. That is to say, the novel manifests itself as a microcosm of the life process starting with birth and ending with death, implying a new beginning. The womb can also be interpreted as a literary space, which has been frequently addressed from the perspective of the mother. Kathleen L. Komar (1994, 90-91) in her article "Feminist Curves in Literary Space" focuses on the metaphorical function of the womb as a literary space and observes that the image is recurrent in women's writing as two different strategies. She asserts,

First, women writers identify female spaces in the external world or indeed they project female spaces onto this outside world. And second, women authors use an opposite strategy for defining and affirming their female selves; they exploit an interior space that is not merely biological (although it is often graphically so) but also psychological. This interior female space is eventually reexteriorized in the form of the literary text, not simply because the women write their stories, but because the space of the text eventually becomes the site of definition and affirmation of the female within and against a male-dominated social structure.

In that sense, the womb is often handled as a space disrupted by the patriarchal power mechanisms and therefore worked on as part of the feminist discourse.

Conversely, what is noteworthy here is that Nutshell tackles the experiences of an unborn baby in a womb, which provides the reader with the first-hand perspective, not of the mother, but of the baby. It is no surprise that while the womb offers space for the baby, it is often the emotional and physical state of the mother that is at stake. This narrative strategy shows that McEwan also goes beyond the conventions of feminist discourse making his postmodern attitude vibrant. The mother's womb is said to form an ambiguous space that starts life, but in this case it also becomes a place where the foetus seems to be entrapped. He acts, thinks and narrates freely in spite of all the chaos arising in his environs. Additionally, his mother's body becomes both the manifestation of his confinement and a free space where he can sneak in others' lives easily. While he becomes almost an omniscient narrator with his most potent omniaudience, he suffers from his mother's actions. Since the comfort and welfare of the womb is directly related to the condition of its owner, it becomes a dubious space that mostly determines the future identity and motives of the baby. He is able to follow what is happening outside, and thus he can somehow respond to it. He is stuck in there waiting for the right time to be born. What renders him particular is not only that he is able to follow the incidents around 
him, but also he can mull over many different subjects within his so-called limited experience. Consequently, the womb, as the means for both his confinement and his freedom creates an ambivalent literary space which contributes to the mysterious flow of events in the novel; yet the sharp distinction between confinement and freedom achieved by this space, paves the way for the interpretation that the plotting of the instances does not truely let one come up with dependable cause and effect relations. Therefore, one of the main principles of enlightenment thought is subject to collapse any time.

Another point that requires consideration is that what is lacking in the world of the unborn child is the sense of seeing; he cannot see anything, but he can figure out his surroundings through his other sensory organs. In this respect, the novel negates the dominant doctrine of the Enlightenment, of "seeing is believing". Since the eye is said to be the most trustworthy organ of enlightenment, Nutshell, portraying the impossibility of observation, primarily foreshadows how it is going to turn the classic ideals upside down into a postmodern gist in the course of the text. In a similar vein, the narrator carries the contradiction of reliability and unreliability in that he might sometimes vocalize childish apprehensions while observing bitter aspects of the life he is a part of and makes solemn interpretations. Ian McEwan, thus, makes clear the fact that the naked eye cannot be the only source of true knowledge. In that sense - though McEwan himself regards his narrator the most reliable one in that he is able to hear, taste, smell and feel everything - one can come to the conclusion that he is making a criticism of enlightenment by allowing the reader to grasp the experiences of a foetus and putting emphasis on other senses rather than the eye (Taken from the interview made by Christopher Beha).

Anthony Synott $(1992,619)$ in his essay entitled "The Eye and I: A Sociology of Sight" discusses the aspects and significance of the eye and how it relates to the I. He elucidates the bond between our language and the ocularcentrism of our culture, quoting from Walter Ong:

Sight is equated with understanding and knowledge in much of our vocabulary: insight, idea, illuminate, light, enlighten, visible, reflect, clarity, survey, perspective, point of view, vision, observation, show, overview, farsighted 9. . you see? (cf. Ong, 1977, 133; Jay, 1986). Similarly, the antonyms of these terms imply a lack of knowledge and understanding: blind, unclear, dim, obscure, hidden, dark, invisible, cloudy. And all these terms carry a heavy load of intellectual and emotional negativity.

Bearing in mind that we are living in a "visual age" (Synott 1992, 621) the sense of sight has gained much importance; nevertheless, if seeing provides a mechanism of authority in relation to knowing, then it is bound to remain on the target board of postmodernism and constantly be questioned. What McEwan accomplishes in Nutshell is that he brings about the most reliable narrator (in his words) lacking the most important sense. In other words, "seeing" may not always directly mean believing, controlling or perceiving.

Furthermore, the novel inherently employs a rewriting and reinterpretation of Shakespeare's prominent and yet desolate Hamlet. It depicts the love relation between Trudy (Gertrude) and Claude (Claudius) who is the brother of Trudy's husband, John Cairncross (in the place of Hamlet's father), an unsuccessful poet. Trudy and Claude embark on a plan to get rid of John for the sake of money. The narrator who can be addressed as "the baby Hamlet" has to remain silent due to his confinement and has only the freedom of making intellectual meditations. His motionlessness according to the regular practices of the outside world bestows the possible grounds to witness everything. He cannot put any actions into practice, but this passivity makes him a perfect observer; he is omniscient and he has nothing to do but grow up gradually, 
internalise his mother's experiences and interpret life. One of the most crucial accounts of the baby Hamlet reads as follows:

But here's life's not limiting truth - it's always now, always here, never then and there. And now we are frying in a London heatwave, here on an unsound balcony. I listen to her refill the glass, the plop of plastic cubes, her soft sigh, more anxious than content. A fourth glass then. She must think I'm old enough to take it. And I am. We're getting drunk because even now her lover is conferring with his brother in the windowless office of the Cairncross Press. To divert myself I send my thoughts ahead to spy on them. Purely an exercise of imagination. Nothing here is real (35).

As it can be inferred from this quotation, the baby Hamlet is questioning the notion of reality as the consequence of imagination. He says if imagination is an outcome of rejecting reality, then nothing can be real.

Another instance in Nutshell that displays Hamlet on stage directly is when he says:

"So what's the use of a headache, a heartache? What am I being warned against, or told what to do? Don't let your incestuous uncle and mother poison your father. Don't waste your precious days idle and inverted. Get born and act!" (46).

The baby Hamlet, however, seems much more active than Shakespeare's child. While Hamlet's passivity is more likely to be the result of his profound pathological melancholy, that is, as Harry Slochower puts, "symptomatically expressed in paralysis and or even perversion of love," the narrator of Nutshell suffers from taking up space in the womb of his mother that makes it impossible to move, or take action. Besides, he is an immature baby indeed, is a fact that the reader mistakenly tends to take for granted, which again is due to an expression of a postmodern strategy. Yet, although his sense of morality and value judgement is indeed well sophisticated, his feelings towards his mother carries the irrational aspect of a mother-son relationship on a profound level:

I try to see her and love her as I must, then imagine her burdens: the villain she's taken for a lover, the saint she's leaving behind, the deed she's spoken for, the darling child she'll abandon to strangers. Still love her? If not, then you never did. But I did, I did. I do (47).

The bringing back of very much an Apollonian genre (in Camille Paglia's words) and a classical work with its most canonical writer, indeed displays the very fact that Ian McEwan is in an attempt to challenge a product of classicism. Setting out from the idea in Nietzsche's The Birth of Tragedy, Paglia asserts that ancient Greek tragedy is an invention of western Apollonian ideals; she points out that:

Tragedy is the most western literary genre. It did not appear in Japan until the late nineteenth century. The western will, setting itself up against nature, dramatized its own inevitable fall as a human universal, which it is not. An irony of literary history is the birth of tragedy in the cult of Dionysus. The protagonist's destruction recalls the slaughter of animals and, even earlier, of real human beings in archaic ritual. It is no accident that tragedy as we know it dates from the Apollonian fifth century of Athens' greatness, whose cardinal work is Aeschylus' 
Oresteia, a celebration of the defeat of chthonian power. Drama, a Dionysian mode, turned against Dionysus in making the passage from ritual to mimesis, that is, from action to representation. Aristotle's "pity and fear" is a broken promise, a plea for vision without horror (Paglia 3).

In that vein, through demonstrating the reception of Shakespeare's Hamlet in his outstanding novel, McEwan deliberately achieves a bitter criticism of culture and classicism in a postmodern manner. Moreover, he pointed out in his interview with Christopher Beha that it is not only the classical work of Shakespeare he utilizes, but also Shakespeare himself is present in the identity of baby Hamlet and this is the reason why he makes him use a sophisticated language.

Additionally, Nutshell appears as an expression of one of the most dominant of McEwan's themes, innocence. He juxtaposes knowledge and innocence through the baby Hamlet's intense meditations on very specific topics and the soberness of the murder story. Correspondingly, McEwan, himself affirms that the whole novel can be read as an expression of "paradise lost," which also contributes to the connection of the novel with the problematic relationship between innocence and knowledge (Interview with Christopher Beha). While Trudy listens to the radio and podcasts, the baby, as a so-called manifestation of innocence, almost sucks the knowledge in a sponge-like manner and does not abstain from spitting them up in his speeches. His thirst for knowledge reveals itself when he kicks his mother's abdomen just to wake her up and turn on the radio, which also shows his "active" condition when compared to Shakespeare's Hamlet. Furthermore, his preoccupation with arts and literature actually derives from the fact that his beloved father is a poet, which once again draws a contradiction between him and Hamlet's father who is a tough man. Whereas John Cairncross, as McEwan points out, appears as the "celebration of selfhood". The melancholy and pain he goes through due to his mother has made him think that the root of poetry, even existence, is pain itself, as can be inferred from his remark, "God said, Let there be pain. And there was poetry. Eventually" (46). The universe of literature creates a kind of open space, or the possibility of salvation for him, as it can be observed when he says:

To be bound in a nutshell, see the world in two inches of ivory, in a grain of sand. Why not, when all of literature, all of art, of human endeavour, is just a speck in the universe of possible things. And even this universe may be a speck in a multitude of actual and possible universe (62).

Through the use of poetry and literature, both as a motif and a means to express the feelings of the unborn baby towards his father, Ian McEwan manifests the intense conceit spread to the whole novel by referring to metaphysical poetry as such:

John Cairncross may be considering one last poem. He could wheel out, as he used to before journeys, 'A Valediction Forbidding Mourning'. Those soothing tetrameters, that mature, comforting tone, would make me nostalgic for the sad old days of his visits. But instead he drums his fingers on the table, clears his throat, and simply waits (94).

As it can be deduced from the incorporation of a work of metaphysical poetry, one can acknowledge that the novel manifests itself as displaying some aspects of the genre on a metafictional level. In other words, the McEwan gives the readers clues on the process of writing his novel.

Apart from the intense imagery it employs, Nutshell displays the features of a typical crime fiction, where the baby Hamlet is at work to investigate the crime committed by his mother and uncle, as the eccentric and talented detective who has extraordinary characteristics setting him 
apart from the majority. What is more, the crime committed is a significant one that includes the killing of John Cairncorn and the criminal is a "worthy opponent". Although the official history of detective fiction dates back to Poe's The Murders in the Rue Morgue (1841), it is a genre that has been a part of literary history since the time of the ancient Greek plays. Starting from Oedipus Rex, crime is an aspect that is found in almost every single tragedy. As John Scaggs, quoting Gamini Salgado who gives examples from Seneca's tragedies indicates, the common points between the structures of crime fiction and tragedy, writes,

The first part of the structure identified by Salgado is the exposition of events leading up to the situation requiring vengeance, in revenge tragedy, or investigation, in the crime novel. The second part of the structure is anticipation as the revenger plans his revenge, or the detective investigates the crime. The third step is the confrontation between revenger and victim, followed by the partial execution of the revenger's plan, or, as is often the case with a chronology of crime 11 the detective's investigation in the crime novel, the villain's temporary thwarting of it. The final part is the completion of the act of vengeance, or, in the case of crime fiction, the detective's final success in bringing the villain to justice (Salgado 17qt. in Scaggs 11-12).

Furthermore, he acknowledges that Salgado's model is a step forward to the structure of tragedy described by Aristotle in Poetics (12). He further states,

In Aristotle's outline, tragedy is governed by a unity of plot in which the narrative advances from beginning to end in an ordered sequence of cause and effect. While a unifying conclusion should tie up any loose ends, it can do so, in Aristotle's view, through the use of peripeteia, or ironic reversal, and anagnorisis, which translates as 'recognition' or 'discovery', and describes the moment when the hero passes from ignorance to knowledge. Such a movement from ignorance to knowledge is crucial to the narrative success of both revenge tragedy and crime fiction (12).

In that context, as Scaggs further discusses, Shakespeare's Hamlet also carries the aspects of crime fiction on the grounds that they share the transition point from ignorance to knowledge in common (12). The key concept here is "knowledge," which is an expression of western enlightenment thought. Likewise, the baby Hamlet in Nutshell has shifted from the original one and has become almost like a detective with much of eloquence and sophisticated wit. As Michael Holquist $(1971,141)$ in his essay, "Whodunit and Other Questions: Metaphysical Detective Stories in Post-War Fiction," brings the relation between the detective prototype and enlightenment's urge for rationality into light as such:

The detective, the instrument of pure logic, able to triumph because he alone in a world of credulous men, holds to the Scholastic principle of adequatio rei et intellectus, the adequation of mind to things, the belief that the mind, given enough time, can understand everything. There are no mysteries, there is only incorrect reasoning. This is the enabling discovery Poe makes for later authors; he is the Columbus who lays open the world of radical rationality which is where detectives have lived ever since. 
Lastly, from a Freudian perspective the experiences of the narrator appear as the representation of the conflict between Eros and Thanatos (referred to as death drive(s) by Freud himself) which he addresses as life instinct and death instinct. For Freud, human beings always remain in between life energy which goes hand in hand with creativity, love, self-satisfaction and sexual pleasure and the tendency to eradicate themselves. Besides, these two instincts should coexist in order to render life explainable (Freud 43-44). Subsequently, in "Civilization and Its Discontents," what Freud argues is that civilization is based upon the suppression of instincts that is life energy. On the contrary, Herbert Marcuse in his Eros and Civilization puts emphasis on the necessity of the Eros instinct as a therapeutic and productive force (Marcuse 1966, 5). By merging elements of life and death, Nutshell refers to the delicate balance between human beings' urge for civilization and progress, while they can hardly take life instinct for granted. The concept of civilization can be assumed as associated with knowledge and enlightenment thought and McEwan's major intention in almost all his novels is to deal with what is happening on the margins and the dark side of human nature where he is not competent enough to suppress himself. During his interview with Mark Medley Ian McEwan is asked the question, "This is a novel about birth, but it's also a novel about death. These are life's two universal experiences. You're now 68 - is this something you think about more these days?". His answer is as follows:

\begin{abstract}
Absolutely. There's no escaping it. It presses in on all sides and comes in at trivial moments as well as important ones. How much of my granddaughter's life - she's 2 - will I see? How many summers have I got left? And you feel it in the body, and you feel it in the joints. And you notice with writers how much it affects the later work. And how the characters are carrying the weight of their creator's sense of shortening time. Sometimes you see it in the wish to escape it, and maybe that's why I've got a fetus - my youngest character yet-narrating the book.
\end{abstract}

And these accounts find a place in the novel itself, as the baby Hamlet says,

A toast to love and therefore death, to Eros and Thanatos. It appears to be a given of intellectual life, that when two notions are sufficiently far apart or opposed, they are said to be profoundly linked. Since death is opposed to everything in life, various couplings are proposed. Art and death. Nature and death. Worryingly, birth and death. And joyously iterated, love and death. On this last and from where I am, no two notions could be more mutually irrelevant (98).

In conclusion, considering that culture, enlightenment, and classicism are concepts that are related and completing one another, I assert that Nutshell forms a counter discourse, so as to contemplate on the validity of these ideals. The main concern of the novel becomes breaking the sharp distinctions between major dichotomies as a strategy to question the persistence of Classicism and thus forming a fictive dialectic of the Enlightenment as a part of cultural criticism. To put it more simply, as enlightenment ideals and classicism are considered as the two main components of culture, Nutshell becomes the accentuation of cultural criticism through forming a dialectic of the enlightenment. The novel utilises many different strategies to achieve this as if a certain methodology is applied, or one can claim that every single detail is a product of meticulous construction that all the components of the content are flawlessly in accord. First, the depiction of the womb as a two-dimensional space, both confined and unrestricted provides an alternative outlook as opposed to conventional connotations of womb. Secondly, the umbilical cord which ties the protagonist to his mother, along with his over- 
critical and erudite meditations enunciate the problem of existence that is an ongoing problematic in the whole novel. Then, the integration of a major canonical text, taking its roots from Ancient Greece as far as the genre is concerned, as an intertext, appears to be one of the most significant manifestations of the writer's attempt to question the dominance of grand narratives and the authority of the notion of the canon, which is again an articulation of a postmodern strategy. Besides, the baby Hamlet might be a reinterpretation of the tragic hero of the classical Shakespeare play, and so is the novel itself. However, the end of Nutshell remains ambiguous with the words, "The rest is chaos," unlike the works of classical tragedy that end up with "culture" pounding the table and makes its own authority evident. At this point, Nutshell becomes a postmodern interpretation of a genre that is the most classical of the classical literary texts in the form of a decadent tragedy and a political dystopia as well. Finally, the novel also attempts to ponder the concept of innocence by making the youngest baby speak for himself. In the $21^{\text {st }}$ century, babies are not necessarily envisaged as the essential reflection of purity anymore. As a result, Ian McEwan's novel, while demonstrating an unusual mode of narration, presents a comprehensive cultural criticism by touching upon all these issues in a divergent context and exhibits in a blatant manner his postmodern attitude.

\section{REFERENCES}

Aristot. (=Aristoteles, Poetika). Source: Aristotle, Poetics. Trans. A. Kenny. Oxford 2013.

Beha C., (Interview with Ian McEwan). Retrieved on 14 January 2019 from https://www.pw.org/ content/ian_mcewans_nutshell

Freud S. (1961). Civilization and Its Discontents. Trans. P. Gay. New York 1961.

Freud S. (1961). Beyond the Pleasure Principle. Trans. J. Strachey. New York 1961.

Holquist M. (1971). "Whodunit and Other Questions: Metaphysical Detective Stories in Post-War Fiction". New Literary History Volume 3 No 1: Modernism and Postmodernism: Inquiries, Reflections, and Speculations (1971) 135-156. Baltimore. Source: http://www.jstor.org/stable/ 468384. Retrieved 23/03/2013.

Komar K. (1994). "Feminist Curves in Literary Space". Eds. M. Higonnet \& J. Templeton, Reconfigured Spheres: Feminist Explorations of Literary Space (1994) 89-108. Massachusetts.

Marcuse H. (1966). Eros and Civilization: Philosophical Inquiry into Freud. Boston 1966.

McEwan I. (2016). Nutshell. London 2016.

Medley M., (Interview with Ian McEwan). "Ian McEwan Feels 'A Sense of Return' with His New Novel, Nutshell”. The Globe and Mail. Retrieved 2016, April 20. https://www.theglobeandmail.com/arts/ books-and-media/ian-mcewan-feels-a-sense-of-return-with-his-new-novel-nutshell/article31798635/

Nietzsche F. (1995). The Birth of Tragedy. United Kingdom 1995.

Paglia C. (1991). Sexual Personae: Art \& Decadence from Nefertiti to Emily Dickinson. London 1991.

Scaggs J. (2005). Crime Fiction. The New Critical Idiom. New York 2005.

Slochower H. (1970). Mythopoesis: Mythic Patterns in the Literary Classics. Detroit 1970.

Synott A. (1992). "The Eye and I: A Sociology of Sight". International Journal of Politics, Culture and Society 5/4 (1992) 617-636. 